\title{
Government Expenditure and Education Sub-sector Development in Nigeria: An Empirical Investigation
}

\author{
Stephen Ebhodaghe Ughulu ${ }^{1,}$, , Stella Eghoikhunu Ughulu ${ }^{2}$ \\ ${ }^{1}$ Department of Banking and Finance, Igbinedion University, Okada, Edo State, Nigeria \\ ${ }^{2}$ Department of Political Science and Public Administration, Igbinedion University, Okada, Edo State, Nigeria \\ Email address: \\ stephenughulu46@gmail.com (S. E. Ughulu), stella4excel@yahoo.com (S. E. Ughulu) \\ ${ }^{*}$ Corresponding author
}

\section{To cite this article:}

Stephen Ebhodaghe Ughulu, Stella Eghoikhunu Ughulu. Government Expenditure and Education Sub-sector Development in Nigeria: An Empirical Investigation. International Journal of Accounting, Finance and Risk Management. Vol. 5, No. 3, 2020, pp. 149-156. doi: 10.11648/j.ijafrm.20200503.14

Received: December 2, 2019; Accepted: March 27, 2020; Published: August 4, 2020

\begin{abstract}
This paper examined empirically the impact of government expenditure on the education sub-sector development in Nigeria for the period 1980 to 2017. Government expenditure was decomposed into capital and recurrent expenditures, while education sub-sector development was viewed from the perspectives of the States and Local Governments dependence (FDR), fiscal concentration (FCR), and per capita income (PCI). The data of the study were obtained from both the National Bureau of Statistics and the Central Bank of Nigeria Statistical Bulletins. The fully modified ordinary least squares (FMOLS) approach of the econometrics was used to estimate the findings/results of the paper. Some of the major findings of the paper indicated that all the variables became stationary after first differencing and that the series for all the equations were cointegrated thereby suggesting the existence of long run relationships among the variables. The short run dynamics results were robust and impressive given that each of the coefficients of determination (R-squared) and their adjusted counterparts were quite high. Furthermore, the results indicated that while capital expenditure exerted negative impact on the education sub-sector development, recurrent expenditure displayed a positive impact on the sub-sector. The paper therefore recommends that government, as a matter of frantic efforts and deliberate policies, scales up its capital expenditure on education sub-sector development as well as intensifying capacity building that would engender qualitatively improved education service delivery. This would only be possible if urgent institutional frameworks, procedures and governance styles that accord with international standards are urgently introduced and implemented.
\end{abstract}

Keywords: Government Expenditure, Education Sub-Sector, Nigeria, Fully Modified OLS

\section{Introduction}

For several years now, the services sector (of which education is a component) has contributed the largest share towards the growth of the Nigerian economy. In fact, the sector significantly outgrew both the agricultural and the oil and gas sectors of the economy which ordinarily were expected to play leading roles in driving the growth of the economy. This situation has aroused interest in the processes and patterns in which the sector has contributed to growth in recent times. Although services take various forms, human capital development (especially formal education) is a very important component of any economic life. Hence, it has been well-documented and widely accepted that investment in education is critical to economic growth and social cohesiveness of a country. The reason for this may not be far-fetched. There are several potential benefits to society from various types of public investment in education; unfortunately, such benefits are not immediately noticeable regardless of their crucial nature.

Thus, schooling is an essential part of education and, hence, the role of improved schooling has been identified as a major part of the development strategies of modern economies as well as international organizations. No wonder, officially published data show certain significant improvements in school attainment across the developing world in recent decades. In this regard, [1] notes that policy 
thrust on schooling has mirrored the emphasis of research on the role of human capital in growth and development. This emphasis, notwithstanding, has also become controversial because the expansion of school attainment has not guaranteed improved economic conditions, especially in the Nigerian context. Furthermore, there has been concern about the research base as questions have been raised about the interpretation of empirical growth analyses. Thus, it seems that both policy questions and research questions are closely related to the measurement of human capital with school attainment. In addition, human capital theory as well as the endogenous growth theory suggests that there are substantial economic effects of education on both the micro and macro levels of the economy [2].

Since the beginning of the 1960 s, the analysis of economic return to education has become a veritable tool for fostering economic progress in developing countries including Nigeria. In other words, the role and effectiveness of education in modern economic systems have been well documented in the extant literature, [3-7]. The empirical findings of these authors point to the fact that education is a basic human need and a key factor in economic development. Invariably, therefore, investment in education tends to directly raise the well-being of the people and also enhance their 'human value' and capacity to acquire means of the satisfaction of other basic needs. Thus, education can be seen as a means of reducing inequality, as a mechanism for making other investments more productive and as an avenue for social and political development.

Given the foregoing background, it seems obvious that the education sector is primarily responsible for human capital development in Nigeria and any other country for that matter. Unfortunately, the authorities in Nigeria seem to have been providing inadequate budgetary allocations to the sector for quite some time now. This has often led to the abysmal performance of the sector despite its importance to the economic growth and development that the country is in dire need of. The main aim of this paper therefore is to investigate empirically the impact of government expenditure on the education sub-sector development in Nigeria and, invariably, the overall Nigerian economy for the period 1980 to 2017.

\section{Literature Review}

Several studies on government spending on the education sector exist in the empirical literature. For example, [8] asserts that Nigeria's government spending on the education sector has been totally inadequate or that the amount purported to have been expended on the sector was not actually spent. In fact, [9] observed that government expenditure on education and the share of total spending to the gross domestic product (GDP) has been declining. For instance, the share of education in Nigeria's total government expenditure between 1970 and 1998 was less than 26 per cent of GDP [10], which was below the United Nations Educational Scientific and Cultural Organization (UNESCO) minimum standard of 26 per cent. This poor funding of education in the country is said to be partly responsible for the poor performance of the sector and its contribution to the GDP, per capital GDP; and other human development indicators.

In their study, [11] examined the role of government in financing education in Nigeria by taking a historical perspective of the involvement of the public sector in education in Nigeria. The pattern of involvement in education over the decades since the colonial era was put in historical perspective and used to compare the nature of involvement in current period. It was noted in the study that though the funding of education has increased in terms of value and amounts, its relative share was actually low when compared with other countries, making the impact of funding on the performance of the educational system to become weak in recent times.

Investigating the nexus between education expenditure and economic growth in Nigeria using the autoregressive distributed lag (ARDL) and the bound test approach, [12] reported that while recurrent educational expenditure was statistically significant in terms of economic growth, capital educational expenditure exerted an insignificant impact on economic growth in both the short run and long run. On the contrary, [13] reported that both government recurrent expenditure and capital expenditure exerted positive impacts on economic development in Nigeria from the period 1970 to 2014.

In their empirical study on government education spending and education outcome in Nigeria from the period1970 to 2013, [14] found that government expenditure on education showed a positive effect on education outcome during the period under review. This finding prompted the authors to conclude that the relevance of education to human and economic development is unarguable. Similarly, [15] investigated the effect of public spending on the growth of the education sector in Nigeria for the period 1981 to 2013 and found that both recurrent and capital expenditures exhibited negative impacts on the educational growth. Furthermore, [16] conducted an empirical investigation into government spending on education and economic growth in Nigeria from 1981 to 2013 and reported that both capital and recurrent spending was positively related to economic. Additionally, they reported that capital expenditure was not statistically significant in the short run due to its insufficient nature but showed a significant impact in the long run.

In another study on budgetary allocation to the education sector in Nigeria, [17] evaluated the influence on the education sector. The study also examined the effect of education expenditure on the level of literacy in Nigeria. Using a time series linear forecasting model, the paper evaluated the effects of the allocation to the education sector by the government and its development. It was found that if certain policy measures such as increased funding, reduced corruption, teachers' motivation and strategic planning among others are fully implemented, the sector will be appreciably developed. It was recommended that government should enhance the allocation of funds to the education sector, and that the private sector should also contribute towards meeting 
UNESCO's recommendation of $26 \%$ of total budget allocation to the sector [18].

\section{Theoretical Framework and Model Specification}

\subsection{Theoretical Framework}

The basic theory upon which the paper is hinged is the [19] model that thoroughly illustrates the effect of government participation in the growth process. In the model, government purchases of goods and services, $\mathrm{G}$, enter into the production function as pure public goods. When a particular sector is considered in a study, and if the production function takes the Cobb-Douglas form, its model will follow that of [19], thus:

$$
Y=A L^{1-\alpha} K^{\alpha} G^{1-\alpha}, 0<\alpha<1,
$$

Where, $K$ is the capital stock.

Equation (1) implies that output of every institution within the sector will exhibit constant returns to scale in the private inputs, Land $\mathrm{K}$. Assuming that the aggregate labor participation, L, is constant. For fixed G, the economy will face diminishing returns to the accumulation of aggregate capital, K, as in the Ramsey model of section two. If, however, $\mathrm{G}$ rises along with $\mathrm{K}$, equation (1) implies that diminishing returns will not arise; that is, the production function specifies constant returns in $\mathrm{K}$ and $\mathrm{G}$ for fixed. For this reason, the economy is capable of endogenous growth, as in the $\mathrm{AK}$ model discussed earlier in this section.

Note also that this form of the production function implies that the public services are complementary with the private inputs in the sense that an increase in $G$ raises the marginal products of $\mathrm{L}$ and $\mathrm{K}$. If the exponent on $\mathrm{G}$ in equation (1) were less than $1-\alpha$, diminishing returns to scale and $\mathrm{G}$ would apply, and these diminishing returns would rule out endogenous growth in the sector. Conversely, if the exponent were greater than $1-\alpha$, growth rates would tend to rise over time.

\subsection{Model Specification}

The model specified in the paper flows from the theoretical foundations of [19] above, which has already been discussed in the preceding sub-section. Accordingly, the model of the paper is simplified to a sectoral growth function where government spending, physical capital and other institutional factors are the economy-wide inputs. Thus, the paper shows that the growth-maximizing relationship between government spending and educational sector development is observed by the coefficients of government spending and educational sector development variables as follows:

$$
\mathrm{y}_{\mathrm{t}}=\alpha_{0}+\alpha_{1} \mathrm{G}_{\mathrm{t}}+\alpha_{2} \mathrm{I}_{\mathrm{t}}+\mathrm{X}_{\mathrm{t}} \beta+\mathrm{u}_{\mathrm{t}}
$$

Where, $y$ is the measure of educational development, $G$ is the measure of government education expenditure, $\mathrm{I}$ is a measure of institutional factor in the country, and $\mathrm{X}$ is a vector of other explanatory variables used as control. Note that the institutional factor included in the model shows the level of fiscal relations between state and federal government This factor is assumed to have a strong impact on public spending outcomes on the educational sector [20]. Following [21], the paper adopts two measures of institutional quality that are thought to be suitable for empirical analysis that is concerned with the fiscal federalism structure of the political system in Nigeria:

a) Fiscal dependency ratio $(F D R)=$ federal allocated revenue as a percentage of total expenditure of states; and

b) Fiscal concentration ratio $(\mathrm{FCR})=$ share of federal government expenditure in the total expenditure of all tiers of government.

Thus, the expanded form of the model specified for the paper is presented as follows, using the macroeconomic variables already discussed above:

$\mathrm{EDt}=\alpha_{0}+\alpha_{1} \mathrm{GRE}_{\mathrm{t}}+\alpha_{2} \mathrm{GCE}_{\mathrm{t}}+\alpha_{3} \mathrm{FDR}_{\mathrm{t}}+\alpha_{4} \mathrm{FCR}_{\mathrm{t}}+\alpha_{5} \mathrm{PCIt}+\mathrm{Ut}(3)$

Where $\mathrm{ED}=$ educational development measure

$\mathrm{GRE}=$ government recurrent expenditure on education

$\mathrm{GCE}=$ government capital expenditure on education (this takes care of the $\mathrm{K}$ in the initial output equation)

$\mathrm{FDR}=$ fiscal dependency ratio

$\mathrm{FCR}=$ fiscal concentration ratio

$\mathrm{PCI}=$ per capita income

$\mathrm{Ut}=$ Stochastic (Error) Term $\alpha$

$\alpha 0=$ Constant Term or Intercept

$\alpha 1-\alpha 5=$ Parameters of coefficients

The apriori expectations are stated, thus:

$$
\alpha 1, \alpha 2, \alpha 3 \alpha 4>0 ; \alpha<0
$$

\subsection{Description of Variables of the Study}

The macroeconomic variables of the paper are briefly described hereunder:

i. Educational Development (EDt)

Education Sector development involves building capacities for qualitatively improved education service delivery through reform of institutional frameworks, procedures and governance [22]. How the changes in the independent variables of this study have influenced the systematic changes/variations of educational sector development in Nigeria will be empirically established in the study.

ii. Government Recurrent Expenditure (GRE)

Government recurrent expenditure on goods and services is expenditure, which does not result in the creation or acquisition of fixed assets (new or second-hand) [23]. In a similar vein, the [24] defines government recurrent expenditure as the expenditure on goods and services (other than capital assets) used in the process of production within one year including interest on loans. Invariably, government recurrent expenditure consists mainly of expenditure on wages, salaries and supplements, purchases of goods and services and consumption of fixed capital (depreciation). Accordingly, therefore, the salutary impact or otherwise of government expenditure on the educational sector 
development in Nigeria remains an issue to be resolved empirically in this paper.

iii. Government Capital Expenditure (GCE)

Government capital expenditure measures the value of purchases of fixed assets, that is, assets that are used repeatedly in production processes for more than one year [25]. The value is at full cost price and their sales are not deducted. Officially published statistics in Nigeria reveal that government expenditure on the education sector has been rising even though marginally. It is thus appropriate to ascertain empirically the impact of government capital expenditure on the education sector development in Nigeria from 1980 to 2017.

iv. Fiscal Dependency Ratio (FDR)

FDR refers to the percentage of total revenue allocated to the State Governments and Local Governments in Nigeria. There are 36 States and 774 Local Government Councils in Nigeria and they depend heavily on the Federal Government for funds needed for the development of their respective jurisdictions. In other words, the performance of these two tiers of government in terms of economic development depends almost exclusively on the Federal Government allocations. Worst still, these Federal allocations are often-times not regularly released to these levels of government as at when due. The empirical examination of this variable becomes inevitable as the 36 States of the Federation depend heavily on federal allocations for their fiscal operations.

v. Fiscal Concentration Ratio (FCR)

FCR is the share of the national revenue accruing to the Federal Government from the Federation Account. The sharing formula currently in operation in Nigeria indicates that the Federal Government receives 56 per cent, while the State Governments and the Local Government Councils get 24 per cent and 20 per cent, respectively. This archaic formula suggests an over-concentration of funds at the Federal level thereby starving both the State and Local Governments of funds needed for the development of their respective jurisdictions. It therefore becomes important to investigate empirically how this concentration phenomenon has impacted on the education sector development in Nigeria.

vi. Per Capita Income (PCI)

This is a measure of the amount of money earned per person in a certain area. It can apply to the average per-person income for a city, region or country, and is used as a means of evaluating the living conditions and quality of life in different areas. It can be calculated for a country by dividing the country's national income by its population. In Nigeria, the average per-person income is less than $\$ 200$ per annum. Thus, it seems inevitable to examine empirically the way and manner this meager per capita income has impacted on education sector development in Nigeria.

\section{Analysis and Interpretation of Empirical Results}

The analysis of empirical result carried out in the paper involves the use of both statistical and econometric methods in order to provide a rich background for the investigation. The statistical tools employed are the descriptive statistics, while the econometrics approach (the fully modified ordinary least squares (FMOLS) and the dynamic ordinary least squares (DOLS) was deployed to estimate the hypothesized relationships among the variables contained in the model specified in the paper.

\subsection{Descriptive Statistics}

The descriptive statistics of the time series data for the variables used in the paper are reported in Table 1:

Table 1. Descriptive Statistics.

\begin{tabular}{lllll}
\hline Variable & Mean & Max. & Min. & Std. Dev. \\
\hline SER & 89.69 & 98.38 & 77.47 & 6.06 \\
PTR & 38.83 & 46.09 & 31.09 & 3.26 \\
SERF & 83.26 & 97.13 & 69.74 & 7.89 \\
FDR & 55.71 & 81.69 & 26.68 & 13.71 \\
FCR & 64.55 & 84.95 & 46.49 & 11.04 \\
LABFP & 56.38 & 58.90 & 54.60 & 1.17 \\
SERM & 98.20 & 123.73 & 83.17 & 10.11 \\
URBR & 4.20 & 4.94 & 3.63 & 0.36 \\
RPCI & 52334.9 & 83802.5 & 1857.0 & 18720.2 \\
GFCF & 61.50 & 142.32 & 6.33 & 42.96 \\
REC_EXP & 77.9 & 390.4 & 0.2 & 112.8 \\
CAP_EXP & 58.79 & 615.34 & 0.24 & 112.04 \\
\hline
\end{tabular}

Source: Researcher's Compilation using Stata Software Package (2019).

From Table 1, it can be seen that school enrolment (note that post-primary school enrolment ratio is used in the paper) is relatively high on average with 89.7 per cent over the period of the study. Though this outcome seems high, it leaves much to be desired since it is expected, based on the UNESCO standard, that every child in the country should have access to post-primary education (at least junior secondary school level) in order to be able to read and write. The maximum value is impressive at 98.4 per cent and the standard deviation is very low, implying that the mean value is generally pervasive over the period. The pupil/teacher ratio for post-primary schools appears high on average at 38.83 over the study period. This indicates, on the average, that each teacher is assigned to about 39 pupils in the post-primary schools in Nigeria. In terms of school enrolment for males and females, the outcomes in Table 1 show that average male enrolment is much higher than that of females, as expected. While the mean ratio for males was 98.2 (the maximum value for overall enrolment ratio) that of females is 83.3 per cent (less than the overall enrolment average). This clearly shows that more male children have access to post-primary school education in Nigeria. The mean recurrent expenditure on education is higher than that of capital expenditure. The high personnel costs (teachers and other associated services) in the sector triggered this type of spending pattern.

The fiscal dependency ratio is 55.7 per cent on average and suggests that the States depend heavily on the Federal Government for their fiscal sustenance. Moreover, the average fiscal concentration ratio of 64.55 per cent shows that more of 
the fiscal resources are concentrated in the center in Nigeria. This possesses serious challenges in financing educational expenditures, which burden is carried by the States rather than the Federal Government in Nigeria. The rate of urbanization which is also a factor that can affect educational development is relatively high on the average at 4.2 per cent. This shows that more pressure is exerted on the urban post-primary schools infrastructure every year. Average real per capita income stood at just over 52 thousand naira for the period, while the rate of infrastructural development (GFCF) is relatively low at 61.5 billion on the average over the period covered by the paper.

\subsection{Econometric Results}

\subsubsection{Unit Root Test Results}

Following the algorithm outlined in the methodology section, the first step of the analysis is to check for stationarity properties of the series used in the study. A time series is stated as non-stationary if mean and variance of the time series are dependent over time [26]. On the other hand, a time series is stated as stationary if the mean and variance is constant over time. According to [26], most economic time series are non-stationary and only achieve stationarity at the first difference or at a higher level. The importance of stationarity of time series used in regression borders on the fact that a non-stationary time series is not possible to generalize to other time periods apart from the present. This makes forecasting based on such time series to be of little practical value. Moreover, regression of a non-stationary time series on another non-stationary time series may produce spurious result.

The result of the unit root test is reported in levels and first differences in Table 2 below:

Table 2. The Unit Root Test Results.

\begin{tabular}{llll}
\hline VARIABLE & ADF & VALUE & \\
\hline & Level & First Difference & Remark \\
\hline SER & -2.689 & $-4.199^{*}$ & $1(1)$ \\
PTR & -3.067 & $-5.442^{*}$ & $1(1)$ \\
SERF & $-3.279^{*}$ & $-3.971^{*}$ & $1(0)$ \\
SERM & -2.14 & $-5.022^{*}$ & $1(1)$ \\
LABFP & -0.93 & $-5.29^{*}$ & $1(1)$ \\
REC_EXP & -1.025 & $-4.811^{*}$ & $1(1)$ \\
CAP_EXP & -0.731 & $-5.074^{*}$ & $1(1)$ \\
FDR & -2.483 & $-6.222^{*}$ & $1(1)$ \\
FCR & -1.575 & $-5.789^{*}$ & $1(1)$ \\
URBR & -1.109 & $-5.529^{*}$ & $1(1)$ \\
RPCI & -0.816 & $-5.851^{*}$ & $1(1)$ \\
GFCF & -1.718 & $-5.245^{*}$ & $1(1)$ \\
\hline
\end{tabular}

Note: * indicates significant at 5\%.

Source: Researcher's Compilation using Stata Software Package (2019).

The general outcome of the results presented in Table 2 indicates that the null hypothesis of the unit roots for the panel data for the variables cannot be rejected when variables are taken in level (except for SERF). This implies that the variables are not stationary in their levels (when the homogenous and heterogeneous results are considered together).
However, we reject the null hypothesis of unit roots when series are in first differences, since the first differences of the variables have statistic values that are significant. These results strongly indicate that the variables are non-stationary in level and stationary in first differences. The test for SERF however shows that the variable is stationary in levels, indicating that the female enrolment ratio does not actually move with time. Since the general results are that the variables became stationary after first difference, we then proceed to establish their long run relationship, thus:

\subsubsection{Cointegration Test}

Normally, the cointegration approach is used to test for a long run equilibrium relationship among the variables. Theoretically, if two series $\mathrm{Y}_{\mathrm{it}}$ and $\mathrm{X}_{\mathrm{it}}$ are both I (1) then it is normally the case that a linear combination between the two will also be $I$ (1) so that a regression of $Y_{i t}$ on $X_{i t}$ would produce spurious results [27]. This is because the residual is also I (1), which violates the assumptions of OLS. However, in a special case, a linear combination of two I (1) variables will result in a variable (residual) which is I (0). Hence, [28] has called such variables cointegrated. This leads to the intuitive interpretation of a cointegrated system as one that represents long-run steady state equilibrium.

For the purpose of this study wherein the dynamic estimation technique is adopted, the Johansen cointegration test procedure is employed. The result of the test is reported in Table 3 below:

Table 3. Johansen Cointegration Tests, Showing hypothesized Number of Cointegrating Equations.

\begin{tabular}{|c|c|c|c|c|}
\hline $\begin{array}{l}\text { Series: } \\
\text { LABFP }\end{array}$ & $\begin{array}{l}\text { Series: } \\
\text { LPTR }\end{array}$ & $\begin{array}{l}\text { Series: } \\
\text { LSER }\end{array}$ & $\begin{array}{l}\text { Series: } \\
\text { LSERM }\end{array}$ & $\begin{array}{l}\text { Series: } \\
\text { LSERF }\end{array}$ \\
\hline \multicolumn{5}{|l|}{ Trace Test } \\
\hline None $*$ & None * & None * & None * & None * \\
\hline At most $1 *$ & At most $1 *$ & At most $1 *$ & At most $1 *$ & At most $1 *$ \\
\hline At most $2 *$ & At most $2 *$ & At most $2 *$ & At most $2 *$ & At most $2 *$ \\
\hline At most 3 & At most 3 & At most 3 & At most 3 & At most 3 \\
\hline At most 4 & At most 4 & At most 4 & At most 4 & At most 4 \\
\hline At most 5 & At most 5 & At most 5 & At most 5 & At most 5 \\
\hline At most 6 & At most 6 & At most 6 & At most 6 & At most 6 \\
\hline At most 7 & At most 7 & At most 7 & At most 7 & At most 7 \\
\hline \multicolumn{5}{|c|}{ Maximum Eigenvalue Test } \\
\hline None * & None * & None $*$ & None * & None $*$ \\
\hline At most 1 & At most $1 *$ & At most $1 *$ & At most 1 & At most $1 *$ \\
\hline At most 2 & At most $2 *$ & At most 2 & At most $2 *$ & At most 2 \\
\hline At most 3 & At most 3 & At most 3 & At most 3 & At most 3 \\
\hline At most 4 & At most 4 & At most 4 & At most 4 & At most 4 \\
\hline At most 5 & At most 5 & At most 5 & At most 5 & At most 5 \\
\hline At most 6 & At most 6 & At most 6 & At most 6 & At most 6 \\
\hline At most 7 & At most 7 & At most 7 & At most 7 & At most 7 \\
\hline
\end{tabular}

Source: Researcher's Compilation using Stata Software Package (2019).

The results in Table 3 above indicate that for the Trace test, up to 2 cointegrating vectors can be detected for each of the sets of estimations in the study. The max-eigen also shows at least one cointegrating vector for some of the series and two for others. Based on these results, we accept that the series for all the equations are cointegrated and thus, a long run relationship exists among the variables. It is also possible to 
analyze a model bearing a long-term identification restriction, since the Johansen cointegration test detects at least five cointegrating relationships within the models.

\subsection{Cointegration Test}

The results of the estimated models, along with the diagnostic test values, are reported in Table 4 below:

Table 4. Estimated models and diagnostic test values.

\begin{tabular}{|c|c|c|c|c|c|}
\hline Variable & Human capital & Teacher ratio & School enrol. & Male enroll. & Female enroll. \\
\hline Constant & $3.72 * *$ & $3.24 *$ & $5.23 * *$ & $7.24 * *$ & $7.10 * *$ \\
\hline LCAP_EXP & 0.02 & 0.02 & 0.001 & $-0.04 *$ & -0.02 \\
\hline LREC_EXP & 0.02 & 0.01 & 0.01 & 0 & 0.01 \\
\hline LFCR & $0.08 * *$ & $-0.29 *$ & $-0.26^{*}$ & $-0.43 * *$ & $-0.55 * *$ \\
\hline LFDR & $0.02 *$ & $0.20 *$ & -0.03 & -0.07 & -0.05 \\
\hline LRPCI & $-0.02 * *$ & -0.01 & 0.01 & -0.01 & 0.01 \\
\hline LURBR & 0.05 & 0.56 & 0.37 & -0.23 & -0.03 \\
\hline R-squared & 0.836 & 0.305 & 0.361 & 0.659 & 0.524 \\
\hline Adj. R-squared & 0.79 & 0.11 & 0.182 & 0.564 & \\
\hline
\end{tabular}

Source: Researcher's Compilation using Stata Software Package (2019).

The results in the Table 4 above show short term relationships among the variables. The results are generally impressive for the variables, apart from that of teacher to pupil ratio and school enrolment ratio. In the results, the adjusted $\mathrm{R}$-squared values for the teacher-pupil ratio and that of overall school enrolments are low, indicating that the explanatory variables explained low proportions of the systematic variations in the dependent variables.

More importantly, the study focuses on the individual coefficients of the variables in terms of signs and significance. A cursory look at each of the coefficients reveals that for the human capital development model, the two government expenditure variables failed the significance test at the 5 percent level. This suggests that in the short run changes in government spending did not have any significant impact on the overall development of human capital in Nigeria. The coefficients of fiscal dependence and fiscal concentration were however significant and both have positive coefficients. The implication of this is that higher concentration of fiscal resources at the centre tends to improve human capital development in the short run. Apparently, federal government spending tends to lead to higher human capital development in the country. The results also showed that both per capita income and fixed capital formation had significant impact on human capital development.

For the teacher-pupil ratio or educational quality model, the results show that neither capital spending nor recurrent spending had significant impact on the variable. This again shows that educational spending does not affect educational quality in the short run. Fiscal concentration ratio has a significant negative impact on educational quality, indicating that the more resources are concentrated in the centre, the less the improvement of quality in the educational sector. This result underscores the importance of concentrating more resources in the States in order to facilitate the quality of education in the country. This is because the State governments tend to be more efficient in the use of resources in the education sector since they are closer to the grassroots and can easily monitor the system. This is more relevant since the model is a short term equation.

The results for the school enrolment rate indicate that only the capital expenditure coefficient was significant (only in the male enrolment equation). This coefficient is negative, indicating that capital spending is shown to have a negative impact on educational sector as only the males had access to education in the short run. The impacts on the other educational access factors are not significant. The overall issue noted from these results is that government spending does not improve educational development in the short run in Nigeria.

The results for the long run estimates are shown from the estimated DOLS estimation shown in Table 5 below:

Table 5. Short run Dynamics Results (FMOLS).

\begin{tabular}{|c|c|c|c|c|c|}
\hline Variable & Human capital & Teacher ratio & School enrol. & Male enroll. & Female enroll. \\
\hline $\mathrm{C}$ & $-2.47 * *$ & -19.88 & $35.62 * *$ & $28.5 * *$ & $52.2 * *$ \\
\hline LCAP_EXP & $0.04 * *$ & 0.35 & $-0.67 * *$ & $-0.67 * *$ & $-0.80 * *$ \\
\hline LREC_EXP & $-0.01 * *$ & -0.17 & $0.22 * *$ & $0.24 * *$ & $0.19 *$ \\
\hline LFDR & $0.00 * *$ & 0.00 & 0.04 & -0.05 & -0.01 \\
\hline LRPCI & $0.35 * *$ & 1.30 & $-0.98 *$ & -0.53 & $-1.63^{*}$ \\
\hline LURBR & $1.26 * *$ & 5.90 & $-9.41 * *$ & $-7.55^{*}$ & $-13.82 * *$ \\
\hline R-squared & 0.99 & 0.88 & 0.99 & 0.99 & 0.99 \\
\hline Adj. R-squared & 0.98 & 0.78 & 0.87 & 0.89 & 0.88 \\
\hline
\end{tabular}

Source: Researcher's Compilation using Stata Software Package (2019).

In the results, each of the models had very impressive goodness-of-fit coefficients. The R-squared and its adjusted 
counterparts are very high, indicating that the selected explanatory variables were able to explain between $78 \%$ and $98 \%$ of the systematic variations in educational development in Nigeria. The results for human capital indicate that all the variables are significant, suggesting that in the long run, human capital development responds to each of the explanatory variables. For the educational expenditure, the results indicate a positive coefficient for capital expenditure and negative for recurrent expenditure. Apparently, it is capital infrastructure in the educational sector that eventually improves the human capital base in the economy in the long run. When human capital is considered from the perspective of skills acquisition and technological/managerial competence, this result is quite relevant. All the other variables, apart from GFCF are shown to have positive impact on human capital development in the long run. For the GFCF variable, the results suggest that physical and human capital tend to be supplementary in terms of their long run relevance in the economy.

The results for educational quality again show that educational spending does not have significant impact on educational quality in the long run. Indeed, none of the variables in the model passed the significance test. This result suggests that improving educational quality in the country goes beyond educational spending and the fiscal arrangement in the country. Perhaps, more efforts, such as institutional improvements, need to be put into the system in order to stimulate quality in the educational sector over time.

For the school enrolment or educational access models, the results show each of the equations has a significant spending coefficient. This shows that educational spending has a very strong impact on educational access in the long run, but weak impacts on the educational quality in the same period. Indeed, more spending has strong effects on access to education in the long term. Educational spending is therefore seen to be a long run affair and the future should always be considered when expenditures are being made in the current period. In the results, capital expenditure had a significant negative impact on all the access measures while recurrent expenditure had a positive impact. These results are rather surprising and suggest that increasing capital expenditure tends to reduce educational access in the long run. The result for recurrent expenditure is quite straight forward since it shows that when recurrent expenditures (such as increasing the number of teachers in the schools) rises, educational access also increases in the long run. Per capita income and urbanization rate both have significant negative impacts on educational access in the long run, with both effects being negative. The results thus show that educational access becomes more limited when the urban centers grow more rapidly.

\section{Summary and Concluding Remarks}

The paper undertook an empirical investigation of the relationship between government expenditure and education sector development in Nigeria for the period 1980 to 2017. Using the officially published data of the Central Bank of
Nigeria, the dynamic framework of the ordinary least squares (DOLS) was deployed to carry out the econometric evaluations of the paper. Some of the empirical results thus obtained showed:

a) That government expenditure exerted long-run impact of education sector development in Nigeria during the period covered by the paper. The implication of this result is that the future must always be given proper consideration when currents expenditures are being made;

b) That capital expenditure had a significant negative impact on all the elements of access measures of educational development, while recurrent expenditure had a positive impact on them. The empirical findings are rather surprising as they suggested that increasing capital expenditure tends to reduce educational access in Nigeria.

Based on the foregoing findings, the paper concluded that government should not only upgrade its spending on education sector, it must also aim at building capacities for qualitatively improved education service delivery through reform of institutional frameworks, procedures and governance that are germane to the attainment of the generally accepted educational standards.

\section{Acknowledgements}

My sincere gratitude goes to Dr. Ekienabor E. for helping to edit and typeset the work.

\section{References}

[1] Obayan, F. O. B. (2006). Educational financing: Principles, trends \& strategies. Ilorin: ACEMDEV Publications.

[2] Hanushek, E. A, Lavy V. \& Kohtaro, K. (2008). Do Students care about school quality? Determinants of dropout behavior in Developing Countries. Journal of Human Capital, https://www.journals.uchicago.edu/doi/pdfplus/10.1086/529446.

[3] Barro, R. (1988). Economic growth in a cross-section of Countries. Quarterly Journal of Economics, 106 (2), 407-43.

[4] Mankiw, N. Gregory, David Romer, and David N. Weil, (1992) "A Contribution to the Empirics of Economic Growth", Quarterly Journal of Economics, 107, 407-37.

[5] Carvalho S, White H (1994) Indicators for poverty reduction. World Bank Discussion Paper 254. World Bank, Washington D. C.

[6] Durlauf, S. N. \& D. T. Quah. (1999). The new empirics of economic growth. In Taylor, J. B. \& Woodford, M. (eds.) Handbook of Macroeconomics, North-Holland, Amsterdam, 231-304.

[7] Omojimite, B. U. (2010). Education and economic growth in Nigeria: A Granger Causality analysis. African Research Review, 4 (3a), 90-108.

[8] Adenuga, A. O. (2002). Educational expenditure and performance in Nigeria (1970-2000). In. 
[9] Human resources development in Africa, Proceedings of the Nigeria Economic Society Annual Conference, Ibadan Pp. 199-222.

[10] Olaniyi, O. O. \&Adam. J. A. (2003). Public expenditure and human development in Nigeria. In human resources development in Africa. Proceeding of the Nigeria Economic Society Conference. Ibadan pp. 157-198.

[11] Central Bank of Nigeria (2010): Annual Report and Statements of Accounts and Statistical Bulletin.

[12] Irughe, I. R and Adegboye, A. C. (2014). Government intervention in education in Nigeria: Are there funding and sustainability issues? Paper Presented and the 3rd COEASU conference, Ilorin.

[13] Ayeni, Abiodu O. \& Omobude, Osagie F. (2018). Educational expenditure and economic growth nexus in Nigeria (1987-2016), Journal for the Advancement of Developing Economies, Vol. 7 Issue1, pp59-77.

[14] Abomaye-Nimnibo, W. A. S., Abomaye-Nimnibo, C. T., Abomaye-Nimnibo, G. B. T. \& Abomaye-Nimnibo, R. A. (2017). The lethargic Government public expenditure torpedoring economic development in Nigeria from 1970-2014, Global Journal of Management and Business Research, Vol. 17, Issue 3, pp.

[15] Obi, C. U, Ekesiobi, S. C., Dimnwobi, S. K., Mgbemena, E. M/ (2016). Government education spending and education outcome in Nigeria, International Journal of Economics, Finance and Management Sciences, Vol. 4, Issue 4, pp. 1-18.

[16] Ojewumi, J. S. \& Oladimeji, W. O. (2016). Effect of public spending on the growth of Educationbal sector in Nigeria, JORIND, 14 (2).

[17] Kabuga, N. A. \& Hssaini, M. (2015). Gobernment spending on education and economic growth in Nigeria: an empirical investigation, Kano Journal of Educational Studies (KAJEST) Vol. 4 (3), December, 2015, pp. 225-236.

[18] Oriakhi, D. E. and Ameh, G. (2014). Government expenditure and the development of the education sector in Nigeria: An evaluation. Review of Public Administration and Management, 3 (5): 103-131.

[19] UNESCO (2014). EFA Global Monitoring Report 2013/4 Teaching and learning: Achieving quality for all, Paris.

[20] Barro, R. J. (1990). Government Spending in a Simple Model of Endogenous Growth. Journal of Political Economy, 106, 407-444.

[21] World Bank (2000). Nigeria Education Sector Analysis: An Analytical Synthesis of Performance and Main Issues. Reports prepared by Prof. Teboho Moja.

[22] Jimoh (2003). Fiscal federalism: The Nigerian Experience. In Fiscal Policy and Growth in Africa: Fiscal Federalism, Decentralization and the Incidence of Taxation, Economic Commission for Africa Ad-Hoc Expert Group Meeting, UNCC, Addis Ababa, October 7-9.

[23] Giz https://www.giz.de/en/worldwide/18006.html)Technical Cooperation Services to the Khyber Pakhtunkhwa Education Sector Plan Support Programme (KP-ESPSP).

[24] Australian Bureau of Statistics: Government Finance Statistics 1999.

[25] CBN (2009) Central Bank of Nigeria Statistical Bulletin.

[26] Gujarati, D. N. (2013): Basic econometrics, 5th Edition, Tata McGraw-Hill Publishing Company Limited, New Delhi, 780-850.

[27] Gordon, D. V. (1995). Optional Lag Length in Estimating Dickey-Fuller Statistics: An Empirical Note, Applies Economic Letter, 2 (6), 188-90.

[28] Iyoha, M. A. (2004) Applied Econometrics. Revised Edition, Mindex Publishing, Benin City.

[29] Granger, C. W. J. (1981). Some properties of time series data and their use in econometric model specification. Journal of Econometrics 16, 121-30. 